\title{
Front Matter: Volume 7406
}

, "Front Matter: Volume 7406," Proc. SPIE 7406, Nanoepitaxy: Homo- and Heterogeneous Synthesis, Characterization, and Device Integration of Nanomaterials, 740601 (11 September 2009); doi: 10.1117/12.844944

SPIE Event: SPIE NanoScience + Engineering, 2009, San Diego, California, United SPIE. States 


\section{PROCEEDINGS OF SPIE}

\section{Nanoepitaxy: Homo- and Heterogeneous Synthesis, Characterization, and Device Integration of Nanomaterials}

M. Saif Islam

A. Alec Talin Stephen D. Hersee Editors

3-4 August 2009

San Diego, California, United States

Sponsored and Published by SPIE 
The papers included in this volume were part of the technical conference cited on the cover and title page. Papers were selected and subject to review by the editors and conference program committee. Some conference presentations may not be available for publication. The papers published in these proceedings reflect the work and thoughts of the authors and are published herein as submitted. The publisher is not responsible for the validity of the information or for any outcomes resulting from reliance thereon.

Please use the following format to cite material from this book:

Author(s), "Title of Paper," in Nanoepitaxy: Homo- and Heterogeneous Synthesis, Characterization, and Device Integration of Nanomaterials, edited by M. Saif Islam, A. Alec Talin, Stephen D. Hersee, Proceedings of SPIE Vol. 7406 (SPIE, Bellingham, WA, 2009) Article CID Number.

ISSN 0277-786X

ISBN 9780819476968

Published by

SPIE

P.O. Box 10, Bellingham, Washington 98227-0010 USA

Telephone +1 3606763290 (Pacific Time) · Fax +1 3606471445

SPIE.org

Copyright (C) 2009, Society of Photo-Optical Instrumentation Engineers

Copying of material in this book for internal or personal use, or for the internal or personal use of specific clients, beyond the fair use provisions granted by the U.S. Copyright Law is authorized by SPIE subject to payment of copying fees. The Transactional Reporting Service base fee for this volume is $\$ 18.00$ per article (or portion thereof), which should be paid directly to the Copyright Clearance Center (CCC), 222 Rosewood Drive, Danvers, MA 01923. Payment may also be made electronically through CCC Online at copyright.com. Other copying for republication, resale, advertising or promotion, or any form of systematic or multiple reproduction of any material in this book is prohibited except with permission in writing from the publisher. The CCC fee code is 0277-786X/09/ $\$ 18.00$.

Printed in the United States of America.

Publication of record for individual papers is online in the SPIE Digital Library.

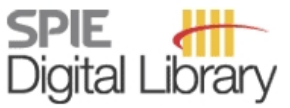

SPIEDigitalLibrary.org

Paper Numbering: Proceedings of SPIE follow an e-First publication model, with papers published first online and then in print and on CD-ROM. Papers are published as they are submitted and meet publication criteria. A unique, consistent, permanent citation identifier (CID) number is assigned to each article at the time of the first publication. Utilization of CIDs allows articles to be fully citable as soon they are published online, and connects the same identifier to all online, print, and electronic versions of the publication. SPIE uses a six-digit CID article numbering system in which:

- The first four digits correspond to the SPIE volume number.

- The last two digits indicate publication order within the volume using a Base 36 numbering system employing both numerals and letters. These two-number sets start with 00, 01, 02, 03, 04, $05,06,07,08,09,0 A, 0 B \ldots 0 Z$, followed by 10-1Z, 20-2Z, etc.

The CID number appears on each page of the manuscript. The complete citation is used on the first page, and an abbreviated version on subsequent pages. Numbers in the index correspond to the last two digits of the six-digit CID number. 


\section{Contents}

$\checkmark$ Conference Committee

vii Sub-nanometer resolution for the inspection of reflective surfaces using white light (Plenary Paper) [7405-37]

W. Jüptner, T. Bothe, Bremer Institut für angewandte Strahltechnik (Germany)

\section{SESSION 1 NOVEL NANOSTRUCTURE SYNTHESIS}

740605 Incorporation of novel ternary Sn-Ga-O and $\mathrm{Zn}-\mathrm{Ga}-\mathrm{O}$ nanostructures into gas sensing devices (Invited Paper) [7406-04]

L. Mazeina, S. M. Prokes, S. P. Arnold, E. R. Glaser, F. K. Perkins, Naval Research Lab. (United States)

740606 Rapid flame synthesis of dense aligned $\mathrm{Fe}_{2} \mathrm{O}_{3}$ nanoneedle arrays (Invited Paper) [7406-05] P. M. Rao, X. Zheng, Stanford Univ. (United States)

\section{SESSION 2 NANOSTRUCTURES FOR DEVICES}

7406 OB Waveguide-integrated nanowire photoconductors on a non-single crystal surface [7406-10] S. Grego, RTI International (United States) and Univ. of California, Davis (United States); K. H. Gilchrist, RTI International (United States); J.-Y. Kim, M.-K. Kwon, M. S. Islam, Univ. of California, Davis (United States)

\section{SESSION 3 WORKSHOP ON NANO-EPITAXY I}

7406 OE Ultrafast carrier dynamics in semiconductor nanowires (Invited Paper) [7406-13] R. P. Prasankumar, P. C. Upadhya, Los Alamos National Lab. (United States); Q. Li, Sandia National Labs. (United States); N. Smith, S. G. Choi, A. K. Azad, D. Talbayev, Los Alamos National Lab. (United States); G. T. Wang, A. J. Fischer, Sandia National Labs. (United States); J. Hollingsworth, S. A. Trugman, S. T. Picraux, A. J. Taylor, Los Alamos National Lab. (United States)

7406 OF Low dimensional III-V compound semiconductor structures (Invited Paper) [7406-14] N. P. Kobayashi, Univ. of California, Santa Cruz (United States) and NASA Ames Research Ctr. (United States)

7406 OG Electronic transport in nanowires: from injection-limited to space-charge-limited behavior (Invited Paper) [7406-15]

F. Léonard, A. A. Talin, A. Katzenmeyer, B. S. Swartzentruber, Sandia National Labs. (United States); S. T. Picraux, Los Alamos National Lab. (United States); E. Toimil-Molares,

J. G. Cederberg, Sandia National Labs. (United States); X. Wang, S. D. Hersee,

A. Rishinaramangalum, The Univ. of New Mexico (United States) 


\section{SESSION 4 WORSHOP ON NANO-EPITAXY II}

7406 Ol Group IV semiconductor nanowire arrays: different flavors of epitaxy (Keynote Paper) [7406-17]

P. C. McIntyre, H. Adhikari, I. A. Goldthorpe, A. F. Marshall, C. E. D. Chidsey, Stanford Univ. (United States)

\section{SESSION 5 WORKSHOP ON NANO-EPITAXY III}

7406 OL Epitaxial science of GaN: nanowires, quantum dots, and mesoscopic morphology (Invited Paper) [7406-20]

Q. Sun, C. D. Yerino, B. Leung, J. Han, Yale Univ. (United States)

SESSION 6 WORKSHOP ON NANO-EPITAXY IV

740600 Growth and electronic properties of $\mathrm{Ge}_{-} \mathrm{Si}_{\mathrm{x}} \mathrm{Ge}_{1-\mathrm{x}}$ core-shell nanowire heterostructures (Invited Paper) [7406-24]

J. Nah, K. M. Varahramyan, E.-S. Liu, A. Opotowsky, D. Ferrer, S. K. Banerjee, E. Tutuc, The Univ. of Texas at Austin (United States)

\section{POSTER SESSION}

7406 OQ Design and simulations of an electrically tunable quantum dot cascade laser [7406-26]

D. Dey, W. Wu, O. G. Memis, H. Mohseni, Northwestern Univ. (United States)

7406 OR Controlled growth of organic nanofibers on nano- and micro-structured gold surfaces [7406-27]

M. Madsen, R. M. de Oliveira Hansen, J. Kjelstrup-Hansen, H.-G. Rubahn, Univ. Of Southern Denmark (Denmark)

7406 0X Formation of dielectric core/metal sheath nanowire composites and their application to SERS sensing [7406-35]

H. Qi, D. A. Alexson, O. Glembocki, S. M. Prokes, Naval Research Lab. (United States)

Author Index 


\title{
Conference Committee
}

\author{
Symposium Chairs
}

David L. Andrews, University of East Anglia Norwich (United Kingdom) James G. Grote, Air Force Research Laboratory (United States)

Conference Chairs

M. Saif Islam, University of California, Davis (United States)

A. Alec Talin, Sandia National Laboratories (United States)

Stephen D. Hersee, The University of New Mexico (United States)

Program Committee

Connie J. Chang-Hasnain, University of California, Berkeley (United States)

Yi Cui, Stanford University (United States)

Aykutlu Dana, Bilkent University (Turkey)

Ravi Dat, Booz Allen Hamilton (United States)

Achyut K. Dutta, Banpil Photonics, Inc. (United States)

Supratik Guha, IBM Thomas J. Watson Research Center (United States)

Mohamed-Ali Hasan, The University of North Carolina at Charlotte (United States)

James S. Im, Columbia University (United States)

Ma Jan, Nanyang Technological University (Singapore)

Savas Kaya, Ohio University (United States)

Nobuhiko P. Kobayashi, University of California, Santa Cruz (United States)

Xianglei S. Mao, Lawrence Berkeley National Laboratory (United States)

Sanjay Mathur, Universität zu Köln (Germany)

Gilberto Medeiros-Ribeiro, Laboratorio Nacional de Luz Sincrotron (Brazil)

Juan Ramon Morante, Universitat de Barcelona (Spain)

S. Tom Picraux, Arizona State University (United States)

Sharka M. Prokes, Naval Research Laboratory (United States)

Giorgio Sberveglieri, Università degli Studi di Brescia (Italy)

Loucas Tsakalakos, GE Global Research (United States)

Lionel Vayssieres, National Institute for Materials Science (Japan)

Priyalal S. Wijewarnasuriya, Army Research Laboratory (United States)

Sungsoo Yi, Sundiode, Inc. (United States)

Chongwu Zhou, University of Southern California (United States) 
Session Chairs

1 Novel Nanostructure Synthesis

Sanjay Mathur, Universität zu Köln (Germany)

Sonia Grego, RTI International (United States)

2 Nanostructures for Devices

Lionel Vayssieres, National Institute for Materials Science (Japan)

Xiaolin Zheng, Stanford University (United States)

3 Workshop on Nano-epitaxy I

A. Alec Talin, National Institute of Standards and Technology (United States)

Jung Han, Yale University (United States)

$4 \quad$ Workshop on Nano-epitaxy II

Jung Han, Yale University (United States)

A. Alec Talin, National Institute of Standards and Technology (United States)

$5 \quad$ Workshop on Nano-epitaxy III

Francois Leonard, Sandia National Laboratory, California (United States)

M. Saif Islam, University of California, Davis (United States)

$6 \quad$ Workshop on Nano-epitaxy IV

M. Saif Islam, University of California, Davis (United States)

Francois Leonard, Sandia National Laboratory, California (United States) 